and 1960. Quickly thereafter, he began his teaching career, first at Indiana University and then at Syracuse University where he was a member of the law faculty and Director of International Legal Studies from 1960 to 1969. In 1968-1969, he held the Charles H. Stockton Chair of International Law at the United States Naval War College, and in 1969 he was appointed to the law faculty of the University of Virginia where, as the Howard W. Smith Professor of Law since 1977, he continued for twenty-seven years until his untimely death last August. Also during these years, he distinguished himself as a Visiting Fellow at Cambridge, Oxford, and the Max Planck Institute in Heidelberg, and at various times he served as a Visiting Professor of Law at New York University, Florida State University, the University of Georgia, and St. Louis University. Beginning in January 1996, he taught, half-time, as the Edward Ball Eminent Professor in International Law at Florida State University.

As is widely known, Professor Lillich and I became serious collaborators, close colleagues, and warm friends, mostly in that order. A very private person, he was not easy to know personally, certainly not quickly. But I do know this: He vigorously sought and displayed energy of mind, body, and spirit in constant and redeeming mix; he was simultaneously a pragmatic realist and zestful idealist; he was analytically and in other ways creative, but also a lover of tradition; he was professionally driven and at the same time ever eager to savor the bounties of life. Perhaps most importantly, he put a high premium on collegial loyalty and other forms of professional friendship, always extending it at least as much as he desired it in return. I and others who knew him are privileged to have had him as our friend. We are all privileged to have had him as our colleague. He will be long remembered and deeply missed.

\title{
Tribute To Michael Cardozo
}

\section{by Frederic L. Kirgis}

Mike Cardozo died of chronic lung disease on October 20, 1996, at the age of eighty-six. He was a leader in legal education and in the American Society of International Law.

After private practice in New York City and stints of government service, including seven years in the Legal Adviser's Office at the State Department, he taught at the Cornell Law School for eleven years, mostly teaching International Law and Conflict of Laws. Then he left to become the first Executive Director of the Association of American Law Schools in Washington. During his time with the AALS, there were many firsts: AALS sections were established; the Faculty Recruitment Conference was begun; Supreme Court Previews were first published; and Law Teaching Clinics were first offered.

He was a member of the ASIL for almost fifty years. From 1978 to 1994 he served as Secretary of the Society. At the time of his death he was an Honorary Vice President. Over the years he served on many Society committees, and was a force especially on the Budget Committee from 1974 to 1990.

Mike had clear and definite opinions and could express them forcefully, yet he wasn't the sort to draw attention to himself. He had a practical rather than theoretical bent, and put it to service for the Society. His sometimes gruff, yet ultimately friendly, presence is missed already in Tillar House. 